\title{
Anticipating PATENTABle SubJeCt MATTER
}

\section{Dan L. Burk*}

The Supreme Court has added to its upcoming docket Association for Molecular Pathology v. Myriad Genetics, Inc., to consider the question: "Are human genes patentable?"1 This question implicates patent law's "products of nature" doctrine, which excludes from patentability naturally occurring materials. The Supreme Court has previously recognized that "anything under the sun that is made by man" falls within patentable subject matter, ${ }^{2}$ implying that things under the sun not made by man do not fall within patentable subject matter. Indeed, the Court has written that items such as "a new mineral discovered in the earth or a new plant found in the wild" would constitute unpatentable products of nature. ${ }^{3}$

One of the recurring arguments for classifying genes as products of nature has been that these materials, even if created in the laboratory, could sometimes instead have been located by scouring the contents of human cells. But virtually the same argument has been advanced and rejected in another area of patent law: the novelty of patented inventions. The rule in that context has been that we reward the inventor who provides us with access to the materials, even if in hindsight they might have already been present in the prior art. As a matter of doctrine and policy, the rule for patentable subject matter should be the same.

* Chancellor's Professor of Law, University of California, Irvine, School of Law.

1. Ass'n for Molecular Pathology v. Myriad Genetics, Inc., 133 S. Ct. 694 (2012) (granting certiorari); Petition for Writ of Certiorari at i, Myriad Genetics, 133 S. Ct. 694 (No. 11-725), 2011 WL 6257250. The Court will hear oral argument in the case on April 15, 2013.

2. Diamond v. Chakrabarty, 447 U.S. 303, 309 (1980) (quoting S. REP. No. 82-1979, at 5 (1952); H.R. REP. No. 82-1923, at 6 (1952)) (internal quotation mark omitted).

3. Id. 


\section{NATURAL AND UNNATURAL DNA}

The patents at issue in Myriad claim DNA sequences that are useful in testing for genes that predispose their carriers to certain forms of breast cancer. Among the DNA molecules challenged in the case are "copy DNA," or cDNAs, of the cancer genes. Such cDNAs are produced in the laboratory by a process called reverse transcription. Reverse transcription uses viral enzymes to produce a DNA copy of RNA transcripts gleaned from human cells. ${ }^{4}$ This process is called reverse transcription because cellular transcription processes normally transcribe RNA from DNA, not the other way around. The cDNAs differ from the native chromosomal DNA sequences because, having been reverse transcribed from RNA transcripts, the cDNAs lack intervening DNA sequences or "introns" that are found in the native chromosomal genes but are edited out of the RNAs produced from chromosomal DNA.

Because the cDNAs differ structurally from native or genomic DNA, Myriad (the patent holder) argued that they must be human inventions, not products of nature. This argument was unanimously accepted by an otherwise divided panel of the Court of Appeals for the Federal Circuit, not once, but twice, after a first appeal from the trial court and again on remand from the Supreme Court. ${ }^{5}$ But opponents of DNA patenting-including scientific research societies - have argued that such cDNAs constitute unpatentable products of nature because it may sometimes be possible to locate them in human cells, not just in the laboratory as the result of human manipulation. Their reasoning is that RNA viruses are found in human cells, which means that the reverse transcriptase enzyme is sometimes active in human cells, and so could sometimes produces cDNA transcripts of human DNA. Because there are billions of human cells in existence, reverse transcription of the Myriad cancer genes somewhere at some time is almost a statistical certainty.

\section{INHERENT ANTICIPATION}

The opponents' argument fundamentally misunderstands and misrepresents the products of nature doctrine. The view they endorse-that because a structure identical or similar to the claimed invention might sometimes be found to occur without human manipulation, the claimed invention fails

4. JAMES WATSON ET AL., MOLECUlar Biology OF THE GENE 749 (6th ed. 2008). Human cells typically use DNA as a template to synthesize messenger RNA (mRNA) molecules. These mRNAs are then used as templates for protein synthesis. Id. at 32-35.

5. Although unanimous on the patentability of cDNA, the panel split over the patentability of other types of DNA molecules. See Ass'n for Molecular Pathology v. U.S. Patent \& Trademark Office, 689 F.3d 1303, 1329 (Fed. Cir. 2012), cert. granted sub nom. Myriad Genetics, 133 S. Ct. 694; Ass'n for Molecular Pathology v. U.S. Patent \& Trademark Office, 653 F.3d 1329, 1349-53 (Fed. Cir. 2011), vacated and remanded sub nom. Ass'n for Molecular Pathology v. Myriad Genetics, Inc., 132 S. Ct. 1794 (2012). 
patentability-effectively imports into patent law's subject matter provisions the doctrine of inherency, in its worst possible formulation. Inherency has generally been associated with the novelty provisions of 35 U.S.C. $\S 102$ in the patent statute. ${ }^{6}$ This statutory section requires that a patentable invention must not be anticipated in the prior art; that is, not previously known or used in the relevant technological field. In the novelty context, inherency addresses the situation where the claimed invention (typically a chemical compound) can in hindsight be recognized to have occurred in some milieu prior to the date of invention. The question is whether the claimed invention can be said to be novel if it existed, albeit unnoticed, prior to the date of invention.

The answer to the inherency question is that making the invention readily available is more important to the patent system than is the invention's prior unappreciated existence. Two famous cases are illustrative. Tilghman $v$. Proctor concerned a method patent for production of fatty acids by breaking down animal fat under heat and pressure. ${ }^{7}$ The patent was challenged for lack of novelty, on the theory that a previously known steam engine, which was lubricated with animal fat, necessarily (although fortuitously) would have identically produced fatty acids by heat and pressure in the course of its operation. Similarly, patent claims to transuranic elements, produced in a nuclear reactor, were challenged for lack of novelty in In re Seaborg. ${ }^{8}$ The Patent Office had rejected Glenn Seaborg's patent application, arguing that the elements claimed in the patent were likely to have also previously occurred in small, unrecognized quantities in nuclear reactors of the type described in a patent disclosure by Enrico Fermi - the design and operation of the reactors made production of the claimed elements physically inevitable.

In each case the novelty challenge to the claimed inventions was rejected, even though the claimed inventions were inherent in prior technology. The courts in these cases held that hindsight realization of the inventions' presence in earlier technologies, recognized only afterward and due to the disclosure of later inventors, did not anticipate the later claims. Fatty acids may have been produced in the prior art steam engine of Tilghman v. Proctor, but no one knew or appreciated their presence. Seaborg's transuranic elements may have been produced in the Fermi nuclear pile, but in quantities that were undetectable had anyone known to look for them. The fact that the inventions may previously have been inherently present, unrecognized or unavailable, in the prior art was of no benefit to humankind. ${ }^{9}$ The disclosure in the subsequent invention made the benefit available, and so garnered the patent reward.

6. Dan L. Burk \& Mark A. Lemley, Inherency, 47 WM. \& MARY L. REV . 371, 375 (2005).

7. 102 U.S. 707, 708-09, 711-12 (1880).

8. 328 F.2d 996, 996 (C.C.P.A. 1964).

9. See Tilghman v. Proctor, 102 U.S. 707, 710-14, 718 (1880); Application of Glenn T. Seaborg, 328 F.2d 996, 998-99 (C.C.P.A. 1964). 
Although there has been occasional judicial confusion regarding this principle of inherency, the clear trend in cases-including the most recent Federal Circuit decisions - has adhered to this analysis. ${ }^{10}$ The question is not whether the claimed invention may fortuitously have occurred in some previous situation, it is whether the public already had the benefit of the invention disclosed by the claimant. Mark Lemley and I have previously shown that this justification should apply not only to anticipation, but also to the products-ofnature discussion. ${ }^{11}$ And so one might ask in the subject matter context, as in the inherent novelty context: did the public have the benefit of the invention as a "natural" constituent of the world, or was it made available for human use by the patentee?

This is the only formulation of the products of nature inquiry that makes any sense as a matter of policy. The exclusive rights of a patent grant are intended largely as a reward for investing the time and effort to bring to the fund of human knowledge some useful technology not previously available. ${ }^{12}$ We do not give patents for technology already available. This is the gist of the inherency inquiry under $\S 102$ : if the public already had the benefit of the invention, there is no need to offer a patent. If we are going to ask about inherency in the context of subject matter, the inquiry should be exactly the same with regard to products of nature: Did the public have the benefit of the claimed invention in some native, natural form? Or was the invention made available to humankind by means of the inventor's ingenuity?

\section{NATURE AS PRIOR ART}

Section 101 of the patent statute says nothing about inherency or about comparing an invention to prior art. The impulse to apply an inherency analysis to products of nature may in part be attributable to a misguided suggestion in the Supreme Court's opinion in Parker v. Flook that products of nature are somehow assumed to constitute "prior art" for the $\S 101$ patentability analysis. ${ }^{13}$ This approach probably misreads the Flook opinion, but even if correct, the Court disavowed it in subsequent decisions. After the Flook decision, the Supreme Court remanded a patentability case, Parker v. Bergy, to the Court of Customs and Patent Appeals for "further consideration in light of

Parker v. Flook." 14 In the lower court's rather dyspeptic reconsideration of Bergy - which concluded that the Flook opinion shed no light whatsoever on the question of patentable subject matter or the proper resolution of Bergy's 2003).

10. See Schering Corp. v. Geneva Pharm., Inc., 339 F.3d 1373, 1379-80 (Fed. Cir.

11. See Burk \& Lemley, supra note 6, at 403-07.

12. Mazer v. Stein, 347 U.S. 201, 219 (1954).

13. Parker v. Flook, 437 U.S. 584, 591-92 (1978).

14. Parker v. Bergy, 438 U.S. 902 (1978). 
claims-Judge Giles Rich very pointedly criticized the Flook opinion for conflating the analysis of patentable subject matter with that of other patentability criteria, such as novelty and nonobviousness. ${ }^{15}$ Judge Rich took particular exception to the concept of prior art in the context of patentable subject matter, as comparison to prior art was relevant only to the separate and distinct steps of determining novelty and nonobviousness.

Subsequently, a new majority of the Supreme Court appears to have taken Judge Rich's critique to heart, citing Bergy II with approval in the later Diamond v. Diehr opinion. Diehr was clearly taken as an opportunity to correct Flook's indiscretions, although the majority stopped short of overruling it. Justice Rehnquist's majority opinion did repudiate the Flook "prior art" dicta: "[i]t is inappropriate to dissect the claims into old and new elements and then to ignore the presence of the old elements in the analysis." 16 The majority then went on (in a footnote) to explicitly reject the reading of Flook that categorized known or natural elements of the invention as "prior art," noting that "[t]o accept the analysis [from Flook] proffered by the petitioner would, if carried to its extreme, make all inventions unpatentable because all inventions can be reduced to underlying principles of nature which, once known, make their implementation obvious." 17

Although Flook has been cited in recent Supreme Court opinions, it has not been cited for its now-discredited "prior art" analysis, nor should it be. ${ }^{18}$ If adopted as the law in Myriad, such an approach would, for example, quickly eviscerate chemical patent practice, particularly in small molecule organic chemistry. Time plus carbon plus heat yields organic molecules, in nearly infinite variety. That is the nature of carbon: it tends to form branching chains of various lengths. We can probably safely assume that any organic molecule imaginable exists or has existed somewhere in the universe at some time in "nature," if only we could hunt long enough or far enough to find it. On this theory, no molecule would ever be patentable. Statistically, they all exist somewhere - in the hydrocarbon fountains of Jovian moons, or the tails of comets, or sulfur vents in the Mariana trench-just as Seaborg's transuranic elements certainly must be found somewhere in nature - say, the outer shells of aged stars.

Despite the putative existence of the Myriad genes or other patented substances in some obscure corner of nature, we want to reward inventors who

15. In re Bergy (Bergy II), 596 F.2d 952, 962 (C.C.P.A. 1979), vacated sub nom. Diamond v. Chakrabarty, 444 U.S. 1028 (1980).

16. Diamond v. Diehr, 450 U.S. 175, 188, 190 (1981).

17. Id. at 189 n. 12 .

18. See Bilski v. Kappos, 130 S. Ct. 3218, 3230 (2010) ("Flook stands for the proposition that the prohibition against patenting abstract ideas 'cannot be circumvented by attempting to limit the use of the formula to a particular technological environment' or adding “insignificant postsolution activity."” (quoting Diehr, 450 U.S. at 191-92)). 
provide access to molecules that were previously giving us no benefit. The hunt for inherent products of nature seems particularly ill conceived as an incentive for innovation. It depends upon inventors' own disclosure, commencing once an inventor has delivered the molecule and we know what we are hunting for. Certainly in the context of patent law's nonobviousness doctrine we do not permit such hindsight second-guessing of the inventor. The invention is to be considered as a whole as it would have been viewed at the time it was created-not dissected into its constituent components and viewed with the benefit of seeing the assembled device. ${ }^{19}$ This policy seems to be the gist of the $\S 102$ inherency cases as well; it may be that with the inventor's contribution in hand, we can conduct a belated search for it amid the prior art, but if no one benefitted from or appreciated the invention until the inventor's disclosure, the invention remains novel for purposes of the statute. And, Justice Rehnquist's footnote in Diamond v. Diehr properly rejects hindsight reconstruction for purposes of $\S 101$ : all inventions can be reduced to obvious natural elements after the fact of their creation, but doing so is not a productive inquiry for determining patentable subject matter.

\section{CONCLUSION}

"I can find the invention somewhere in nature once an inventor has shown it to me" is clearly the wrong standard for a patent system that hopes to promote progress in the useful arts. ${ }^{20}$ The fact that a version of the invention may have previously existed, unrecognized, unavailable, and unappreciated, should be irrelevant to patentability under either novelty or subject matter. The proper question is: did the inventor make available to humankind something we didn't have available before? On this standard, the reverse transcribed molecules created by the inventors in Myriad are clearly patentable subject matter.

19. See 35 U.S.C. $\S 103$ (2011).

20. See U.S. Const. art. I, $\S 8$, cl. 8. 